\title{
European Journal of Tourism Research
}

http://journals.wesro.org/wjejtr.html

\section{Sznajder, L. Prezezbórska, F. Scrimgeour (2009) Agritourism. CABI Publishing. Electronic version. 301 pages. ISBN 978-1-84593-482-8}

\author{
Reviewed by Daniel H. Olsen ${ }^{1 *}$
}

Received: 27/08/2009

\begin{abstract}
${ }^{1}$ Department of Geography, Brandon University, 270 18th Street, Brandon, Manitoba, Canada R7A 6A9; tel: 1-204-727-9766, fax: 1-204-728-7346, e-mail: olsend@brandonu.ca

* Corresponding author
\end{abstract}

(C) 2009 International University College. All rights reserved

Citation: M. Sznajder, L. Prezezbórska, F. Scrimgeour (2009) Agritourism. CABI Publishing. Electronic version. 301 pages. ISBN 978-1-84593-482-8. Reviewed by Daniel H. Olsen European Journal of Tourism Research 2(2), pp. 197-199

The literature on rural tourism has grown over the past number of years as government officials and agriculturalists have seen the potential for both economic and income diversification through tourism (e.g., Getz and Page 1997; Sharpley and Sharpley 1997; Roberts and Hall 2001; Hall, Roberts and Mitchell 2003).

One of the sub-niche markets within rural tourism is agritourism, where tourists engage in recreational activities within an agricultural setting. While a number of journal articles have recently been published looking at this rural tourism niche market (e.g., Nickerson et al. 2001; Kovani 2003; McGehee and Kim 2004; Colton and Bissix 2005; McGehee 2007; barbieri and Mshenga 2008; Shen and Cottrell 2008), Michał Sznajder, Lucyna Prezezbórska and Frank Scrimgeour's book Agritourism is one of the few books (e.g., Butler et al. 1998) to focus specifically on the economic and management issues related to agritourism development.

The book is divided into four distinct sections or "parts". Part 1 introduces the reader to the economics of agritourism, although this section of book is more than an introduction to the concepts and spaces that make up agritourism. In Chapter 1, the authors begin by differentiating between agritourism and rural tourism, and then examine the economic and social importance of this niche-market (Chapter 2). Attention is then given in Chapter 3 to looking at role of agritourism in multifunctional development in rural areas. In Chapter 4, a specifically geographic approach is taken in looking at the qualities and classifications of different types of agritourism spaces, ranging from qualities based on cultural and aesthetic values to classifications relating to function (e.g., cropping space, livestock space, forest space, etc.).

Part 2 revolves around a series of short chapters that examine issues related to both the economics and management of agritourism. Chapter 5 investigates the ventures or business enterprises that participate in developing and running agritourism. Chapter 6 looks at the regulatory bodies and policies that regulate agritourism activities. In Chapter 7, the authors study the 
organization of agritourist farms and compare them to the organization of an agricultural farm, and in Chapter 8 they discuss the economic issues related to running agritourist enterprises. Chapter 9 discusses co-operation and networking amongst agritourism enterprises, and Chapter 10 looks into the different agritourist services and products offered for consumption by agritourism operators. Chapters 11 and 12 look at agritourists and the agritourist market.

Part 3, entitled "Agritourist Entities and Enterprises" (again erroneously labeled), focuses on different agritourism issues. Chapter 13 is an introductory chapter to this section. Chapter 14 focuses on a number of things that facilitate agritourism including souvenirs, information and quality. Chapter 15 looks at the different ways tourists are transported to and through agritourism sites. Chapter 16 summarizes visits the authors had to twenty-two different agritourist farms and enterprises around the world. Chapter 17 is entitled "Agritourism on the Edge" and looks at phenomena related to rural areas that are not considered agritourism per se but are important things for agritourism enterprises to be aware of, such as virtual agritourism and pilgrimage traffic. Chapter 18 focuses on the specific characteristics of agritourists in New Zealand, the Russian Federation, Quebec Canada, the United Kingdom, and Poland.

Part 4 encompasses Chapter 19 which is the concluding chapter for this book. This chapter examines some of the future issues related to agritourism development.

At the end of each chapter there are "Case Studies" sections. The use of the term "Case Studies" is misleading, as rather than providing case studies related to the theories and principles of agritourism discussed in each chapter (as academics generally understand case studies to be) there are a number of questions and suggested activities that readers can answer and to better understand and apply the content of each chapter. These questions and the suggested activities give the impression that this book, making an excellent addition to the research field of agritourism, is also intended to serve as a textbook to possibly graduate students who study the specific niche market of agritourism.

Outside of the mislabeling of the different section headings and the "Case Studies" sections, this book is an excellent theoretical and practical contribution to research on agritourism. An addition criticism is that, Part 3 may have been better off assimilated into the chapters in Part 2 rather than being standalone chapters in their own section. However, the diagrams and charts throughout are useful, pertinent, and professionally done, and the book as a whole is generally well written. This book would be of great value to practitioners, researchers, and students of rural tourism taking a more general interest in the subject and to those who are interested in agritourism more specifically.

\section{References}

Barbieri, C., P. M. Mshenga, (2008) the Role of the Firm and Owner Characteristics on the Performance of Agritourism Farms. Sociologia Ruralis 48(2), pp. 166-183

Butler, R. W., C. M. Hall, J. Jenkins (1998) Agritourism and Recreation in Rural Areas. John Wiley and Sons

Colton, J. W., G. Bissix (2005) Developing Agritourism in Nova Scotia: Issues and Challenges. Journal of Sustainable Agriculture 27(1), pp. 91112

Getz, D., S. Page (1997) The Business of Rural Tourism: International Perspectives. Auckland, NZ: Thomson Learning

Hall, D., L. Roberts, M. Mitchell (eds.) (2003) New Directions in Tourism. Aldershot, UK: Ashgate Publishing Ltd.

Kovani, H. (2003) Agritourism - In Search of Quality. Journal of Rural Cooperation 31(1), pp. 59-73

McGehee, N. G., K. Kim (2004) Motivation for Agri-Tourism Entrepreneurship. Journal of Travel Research 43(2), pp. 161-170 
M. Sznajder, L. Prezezbórska, F. Scrimgeour (2009) Agritourism. CABI Publishing. Electronic version. 301 pages. ISBN 978-1-84593-482-8. Reviewed by Daniel H. Olsen / European Journal of Tourism Research 2(2), pp. 197-199

McGehee, N. G. (2007) An Agritourism Systems Model: A Weberian Perspective. Journal of Sustainable Tourism 15(2), pp. 111-124

Nickerson, N. P., R. J. Black, S. F. McCool (2001) Agritourism: Motivations behind Farm/Ranch Business Diversification. Journal of Travel Research 40(1), pp. 19-26

Roberts, L., D. Hall, (2003) Rural Tourism and Recreation: Principles to Practice. Wallingford, UK: CABI Publishing.
Shen, F., S. P. Cottrell (2008) Sustainable Tourism Framework for Monitoring Residents' Satisfaction with Agritourism in Chongdugou Village, China. International Journal of Tourism Policy 1(4), pp. 368-375.

Sharpley, R., J. Sharpley (1997) Rural Tourism: An Introduction. London and Boston: Nelson Thomson Learning. 